\title{
KEPUTUSAN KONSUMEN DALAM MEMILIH PERUSAHAAN SEBAGAI DAMPAK DARI KELOMPOK REFERENSI DAN NILAI TERHADAP CITRA PERUSAHAAN ASURANSI UMUM DI PROVINSI DKI JAKARTA
}

\author{
Ismayudin Yuliyzar \\ Universitas Muhammadiyah Tangerang \\ ismayudin_yulizar@yahoo.co.id
}

Keyword
Reference Group, Value, Image,
Company, Decision of Use

Abstract

The objectives of this study are: (I) to analyze the effect of perceived value on the company image and its implication to the decision in using general insurance product (2) to analyze the influence of refraction group to the company image and its implication to the decision in using general insurance product perceived and refresni groups to the company image and its implications for the decision in using general insurance products. this research is descriptive and verifikatif. Respondents were 235 customers. The results of this study are: (I) Partial reference group has a positive effect is not significant to Purchase Decision (2) The value perceived by customers partially have a positive and significant impact on Corporate Image (3) Reference Group and Value Perceived Customer together positive and significant to the image of General Insurance Company in Jakarta with the value of determination coefficient (R2) of $48 \%$. (4) Reference group by partial have positive and significant effect to Purchasing Decision, (5) The value of customer perceived by partially have a positive and significant effect to Purchasing Decision (6) Corporate Image partially have positive and significant influence to Purchase Decision (7) Reference Group , Perceived Value of Customers, and Corporate Image together have a positive and significant effect on Purchasing Decision on General Insurance in DKI Jakarta with value of coefficient of determination (R2) equal to $83 \%$.

\section{PENDAHULUAN}

\section{Latar Belakang Masalah}

Industri asuransi berkembang selaras dengan perkembangan dunia usaha pada umumnya. Kehadiran industri asuransi merupakan hal yang rasional dan tidak terelakkan pada situasi di mana sebagian besar anggota masyarakat dan pengusaha memiliki kecenderungan umum untuk menghindari atau mengalihkan resiko kerugian atas segala yang dimiliki. Hal tersebut jika tidak dipertimbangkan upaya perlindungan dari berbagai risiko, dapat menimbulkan kerugian financial yang tidak sedikit. Namun demikian menurut Asosiasi Asuransi Umum Indonesia (AAUI) tahun 2013 menyatakan bahwa "Industri asuransi umum masih mengalami krisis." Tahun 2012, pendapatan premi hanya tumbuh 3,6 persen dan tahun ini kondisinya diperkirakan tidak jauh berbeda". Hal ini menunjukkan bahwa pelaku usaha dan pemangku kepentingan lainnya di industri asuransi umum memang menghadapi tantangan berat dalam menumbuhkan industri asuransi umum di Indonesia.

Prinsip asuransi umum terkait dengan sumber dan penggunaan dana yang berhubungan dengan mobilisasi dana masyarakat dalam bentuk premi dan pengelolaan dana tersebut untuk tujuan investasi. Prinsip tersebut selanjutnya dikaitkan dengan posisi asuransi umum sebagai lembaga keuangan dalam mekanisme circular flow of income atau sebuah model ekonomi sederhana yang menggambarkan saling keterhubungan antara pelaku ekonomi.

Kemudian pada tingkat global, berdasarkan pada World Insurance Outlook(20I4), nilai total premi dunia pada tahun 2013 adalah sebesar US\$ 3723,3 Milyar yang terdiri dari premi asuransi jiwa sebesar US\$2209,3 Milyar dan 
premi asuransi umum sebesar US\$ 1514 Milyar. Angka tersebut meningkat dengan rata-rata sebesar 10,3 persen untuk asuransi jiwa dan hanya 5,0 persen untuk asuransi umum.

Pertumbuhan nilai premi asuransi umum lebih rendah dibandingkan dengan asuransi jiwa yaitu $5.0 \%$ berbanding $10.3 \%$. Demikian juga dengan di Indonesia, pertumbuhan nilai premi asuransi umum hanya sebesar $6,5 \%$ lebih rendah dibandingkan dengan asuransi jiwa yang mencapai pertumbuhan nilai premi asuransinya sebesar 32,4\%.

Berdasarkan data dan analisis dari Lembaga Riset Media Asuransi (2014), sampai dengan Desember 2013, I5 perusahaan asuransi jiwa terbesar berdasarkan premi brutonya menguasai 87\% pasar asuransi jiwa di Indonesia. Sementara I5 perusahaan asuransi umum terbesar berdasarkan premi brutonya menguasai $63 \%$ pasar asuransi umum di Indonesia. Baik 15 market leader asuransi jiwa maupun 15 market leader asuransi umum di industri asuransi Indonesia berdasarkan laporan keuangan publikasi per Desember 2013, ternyata penguasaan pasar premi brutonya mengalami penurunan I\% dari tahun sebelumnya. Berikut adalah 15 market leader asuransi jiwa dan asuransi umum di Indonesia.

Tabel I.Peringkat I5 Besar Asuransi Jiwa dan Asuransi Umum Berdasarkan Premi Bruto di Indonesia Tahun 2013.

\begin{tabular}{|c|c|c|}
\hline \multirow{2}{*}{ Peringkat } & \multicolumn{2}{|c|}{ Nama Perusahaan } \\
\hline & Asuransi Jiwa & Asuransi Umum \\
\hline I & PT. Prudential Life & $\begin{array}{l}\text { PT Asuransi Jasa } \\
\text { Indonesia }\end{array}$ \\
\hline 2 & PT Asuransi Sinar Mas & PT Asuransi Sinar Mas \\
\hline 3 & PT Manulife Indonesia & PT Asuransi Astra Buana \\
\hline 4 & PT Allianz & $\begin{array}{l}\text { PT Tugu Pratama } \\
\text { Indonesia }\end{array}$ \\
\hline 5 & $\begin{array}{l}\text { PT Indolife } \\
\text { Pensiontama }\end{array}$ & PT Asuransi Central Asia \\
\hline 6 & PT AXA Mandiri & $\begin{array}{l}\text { PT Asuransi Wahana } \\
\text { Tata }\end{array}$ \\
\hline 7 & PT Jiwasraya & $\begin{array}{l}\text { Pt Asuransi Adira } \\
\text { Dinamika }\end{array}$ \\
\hline 8 & PT AIA & PT Askrindo \\
\hline 9 & PT Wanaartha & PT Asuransi MSIG \\
\hline 10 & PT Panin Dai-ichi & PT Bina Dana Artha \\
\hline 11 & PT Mega Life & $\begin{array}{l}\text { PT Asuransi Bangun } \\
\text { Askrida }\end{array}$ \\
\hline 12 & PT Sequise Life & PT Ace Jaya Proteksi \\
\hline 13 & $\begin{array}{l}\text { PT Bringin Jiwa } \\
\text { Sejahtra }\end{array}$ & PT Jasaraharja Putera \\
\hline 14 & PT Commonwealth Life & PT Asuransi Rama Satria \\
\hline 15 & PT BNI Life Insurance & $\begin{array}{l}\text { PT Lippo General } \\
\text { Insurance }\end{array}$ \\
\hline
\end{tabular}

Sumber : Media Asuransi, 2014.

Pada tahun 2013 jumlah perusahaan asuransi umum di Indonesia tercatat sebanyak 89 perusahaan dengan mobilisasi dana masyarakat dalam bentuk premi tercatat sebanyak Rp 19,3 triliun. Jika menggunakan data estimasi World Insurance Outlook pada tahun 2013 , nilai premi tersebut hanya 0,6 persen dari PDB Indonesia yang tercatat sebesar US\$ 364 juta. Jika nilai premi tersebut dibagi dengan jumlah penduduk Indonesia yang mencapai 240 juta orang maka premi per kapita untuk Indonesia hanya sebesar US\$9 per orang per tahun. Angka-angka kinerja asuransi umum tersebut dibandingkan dengan asuransi jiwa dan lembaga keuangan bank dapat dilihat pada Tabel I.2 di bawah ini. 
Tabel 2. Perbandingan Kinerja Asuransi Umum, Jiwa dan Perbankan

\begin{tabular}{|c|c|c|c|}
\hline $\begin{array}{l}\text { Indikator } \\
\text { Keuangan }\end{array}$ & $\begin{array}{l}\text { Asuransi } \\
\text { Umum }\end{array}$ & $\begin{array}{l}\text { Asuransi } \\
\text { Jiwa }\end{array}$ & Perbankan \\
\hline $\begin{array}{l}\text { Jumlah } \\
\text { Perusahaan }\end{array}$ & 89 & 46 & - \\
\hline Total Aset & - & 8I Triliun & I80I Triliun \\
\hline $\begin{array}{l}\text { Premi/ Dana } \\
\text { Masyarakat }\end{array}$ & $\begin{array}{c}19,3 \\
\text { Triliun }\end{array}$ & 26,8 Triliun & I 562 Triliun \\
\hline $\begin{array}{l}\text { Persentase } \\
\text { Premi/ } \\
\text { Simpanan } \\
\text { terhadap PDB }\end{array}$ & $0,6 \%$ & $0,8 \%$ & $170 \%$ \\
\hline $\begin{array}{l}\text { Premi/ } \\
\text { Simpanan } \\
\text { Bank } \\
\text { perkapita }\end{array}$ & $\begin{array}{l}\text { Rp. 85,5 } \\
\text { Ribu / } \\
\text { Orang }\end{array}$ & $\begin{array}{l}\text { Rp. I I 8,75 } \\
\text { Ribu / } \\
\text { Orang }\end{array}$ & $\begin{array}{l}\text { Rp. } 6,9 \text { Juta } \\
\text { / Orang }\end{array}$ \\
\hline
\end{tabular}

Sumber : World Insurance Outlook, 2012.

Berdasarkan Tabel I.2 di atas menunjukkan bahwa asuransi umum belum menunjukkan kinerja keuangan yang lebih baik dibandingkan asuransi jiwa apalagi dengan perbankan.

\section{Identifikasi Masalah}

Berdasarkan latar belakang penelitian di atas, maka permasalahan dalam penelitian ini dapat diidentifikasi sebagai berikut :

I. Market leader perusahaan asuransi umum di Indonesia masih relatif kecil dibandingkan dengan market leader pada perusahaan asuransi jiwa, dimana perusahaan asuransi umum hanya mencapai $63 \%$ sementara perusahaan asuran jiwa mampu mencapai $87 \%$ pada tahun yang sama (tahun 2013 ).

2. Kinerja perusahaan asuransi umum relatif masih paling rendah jika dibandingka dengan perusahaan asuransi jiwa, bahkan lebih rendah lagi jika dibandingkan dengan lembaga keuangan (perbankan).

3. Kinerja perusahaan asuransi umum yang paling rendah dibanding lembaga lain di indikasikan dengan rendahnya premi/ dana masyarakat yang dikelola perusahaan asuransi umum hanya sebesar 19,3 Triliun Rupiah, sementara asuransi jiwa mampu mencapai 26,8 Triliun Rupiah. Demikian juga dengan persentase premi terhadap PDB, asuransi umum hanya mencapai $0,6 \%$ sementara asuransi jiwa mencapai $0,8 \%$.

4. Market leader yang relatif kecil dan kinerja yang relatif rendah pada asuransi umum di Indonesia cenderung disebabkan oleh masih rendahnya keputusan pembelian oleh konsumen dalam memilih/membeli asuransi umum.
5. Keputusan pembelian oleh konsumen dalam memilih/membeli asuransi umum yang masih rendah diindikasikan oleh kurang popular asuransi umum di masyarakat, sehingga masyarakat lebih memilih jenis asuransi jiwa dibandingkan jenis asuransi umum.

6. Keputusan Consumeruntuk memilih asuransi disinyalir disebabkan oleh citra dari perusahaan asuransi umum, hal ini diindikasikan oleh tingginya kasus penolakan klaim oleh perusahaan asuransi, sehingga membuat jasa asuransi umum mendapat sorotan tajam dari masyarakat.

7. Citra asuransi umum tertentu, cenderung dipengaruhi oleh nilai yang dirasakan oleh konsumen, berdasarkan survey pendahuluan yang telah dilakukan terhadap 100 konsumen ternyata nilai yang dirasakan responden mengenai asuransi yang dipilihnya tidak sepenuhnya dipersepsikan dalam katagori yang baik.

8. Citra perusahaan asuransididuga dipengaruhi oleh keberadaan kelompok referensi, mengacu pada survey pendahuluan yang sama, ternyata tidak sepenuhnya citra perusahaan asuransi yang ada di benak responden, mereka dapatkan dari seseorang dan atau sekolompok orang sebagai kelompok referensi.

\section{Rumusan Masalah}

Berdasarkan identitifikasi masalah di atas, maka rumusan masalah adalah sebagai berikut:

I. Apakah terdapat pengaruh kelompok referensi terhadap citra perusahaan pada Asuransi umum di Provinsi DKI Jakarta?

2. Apakah terdapat pengaruh nilai yang dirasakan terhadap citra perusahaan pada Asuransi umum di Provinsi DKI Jakarta?

3. Apakah terdapat pengaruh kelompok referensi dan nilai yang dirasakan secara bersama-sama terhadap citra perusahaan pada Asuransi umum di Provinsi DKI Jakarta?

4. Apakah terdapat pengaruh kelompok referensi terhadap keputusan pembelian pada Asuransi umum di Provinsi DKI Jakarta?

5. Apakah terdapat pengaruh nilai yang dirasakan terhadap keputusan pembelian konsumen pada Asuransi umum di Provinsi DKI Jakarta?

6. Apakah terdapat pengaruh citra perusahaan terhadap keputusan pembelian consumer pada asuransi umum di Provinsi DKI Jakarta? 
7. Apakah terdapat pengaruh kelompok referensi, nilai yang dirasakan dan citra perusahaan secara bersama-sama terhadap keputusan pembelian consumer pada Asuransi umum di Provinsi DKI Jakarta?

\section{TINJAUAN PUSTAKA}

Kelompok referensi didefinisikan oleh, Iryna (2008:II5) bahwa, Reference groups are broadly defined as "actual or imaginary institutions, individuals, or groups conceived of having significant relevance upon an individual's evaluations, aspirations, or behavior. Kelompok referensi secara luas didefinisikan sebagai perusahaan aktual atau imajiner, individu, atau kelompok yang dipahami memiliki relevansi secara signifikan dengan evaluasi, aspirasi, atau perilaku individu.

Kotler Philip (2002), kelompok referensi sebagai kelompok yang mempunyai pengaruh langsung maupun tidak langsung terhadap sikapdan perilaku seseorang.

\section{Kelompok Referensi Normatif}

Dawson dan Chatman

mengemukakan kelompok referensi normatif adalah sebagai berikut:

A normative reference group is described as a group in which individuals are motivated to gain or maintain acceptance. To promote this acceptance, individuals hold their attitudes in conformity with what they perceive to be the consensus of opinion (norms) among the group members. In normative reference grouptheory, the group sets and enforces standards for individuals. Such standards are often referred to as group norms; thus we have the "normative function" of reference groups.

Sebuah kelompok referensi normatif digambarkan sebagai kelompok di mana individu yang termotivasi untuk mendapatkan atau mempertahankan penerimaan dirinya dalam kelompok yang dimaksud.

\section{Kelompok Referensi Komparatif \\ Dawson dan Chatman}

mengemukakan definisi dari kelompok rerefensi komparatif dengan pernyataan bahwa istilah kelompok referensi komparatif digunakan untuk menggambarkan sebuah kelompok individu sebagai standar atau titik acuan dalam membuat evaluasi atau perbandingan sendiri dengan individu atau kelompok lain. Dalam teori kelompok referensi komparatif, evaluasi individu oleh anggota kelompok referensi sebagian besar tidak relevan. Dalam kaitannya dengan perbandingan kelompok referensi, kelompok hanyalah standar atau pemeriksaan yang digunakan oleh individu atau orang lain untuk membuat penilaian.

\section{Nilai Yang Dirasakan Pelanggan}

Mosavi and Ghaedi (20II : 250) menyatakan bahwa nilai yang dirasakan pelanggan merupakan nilai yang dipersepsikan oleh pelanggan, sebagaimana yang dinyatakannya bahwa "perceived value has gained recent attention as a stable construct to predict buying behavior. Additionally, customers' value perceptions have been found to increase their willingness to buy and decreas their searc intentions for alternatives”.।

\section{Citra Perusahaan}

Long-Yi Lin and Ching-Yuh Lu (2010:18) menyatakan, "citra perusahaan adalah kombinasi dari persepsi konsumen dan sikap terhadap badan usaha.Robertson dan Gatignon (1986) lebih lanjut menyatakan bahwa, citra perusahaan membantu memfasilitasi pengetahuan konsumen pada produk atau jasa yang ditawarkan oleh perusahaan tertentu dan mengurangi ketidakpastian sementara membuat keputusan pembelian.Konsumen diarahkan untuk membeli komoditas dari sebuah perusahaan dengan citra perusahaan yang baik untuk mengurangi risiko".

\section{Keputusan Pembelian (Purchase Decision)}

Smadi and Al-jawazneh (201I: 104), pengambilan keputusan konsumen didefinisikan sebagai pola perilaku konsumen yang menentukan dan mengikuti proses pengambilan keputusan untuk memuaskan konsumen melalui produk, ide atau jasa.

Jalal kamali dan Nikbin (2010:235) menjelaskan definisi dari keputusan pembelian dengan mengutip pendapat para ahli sebagai berikut, "Schiffman dan Kanuk (2004) mendefinisikan keputusan pemilihan sebagai pilihan dari dua atau lebih alternatif pilihan. Ketika seseorang memiliki pilihan antara melakukan pembelian dan tidak membuat pembelian, pilihan antara merek $X$ dan merek $Y$, atau pilihan menghabiskan waktu melakukan $A$ atau B dari orang yang berada pada posisi untuk membuat keputusan, dalam melaksanakan niat pembelian".

\section{Kerangka Pemikiran}

Mengacu pada hasil penelitian Bahareh Ghotbivayghan, Masoomeh Hoseinzadehshahri, and Mohammad Reza Ebrahimi (20I5) melalui temuan penelitiannya menyatakan bahwa dukungan selebriti (kelompok referensi) 
memiliki efek positif pada citra perusahaan, kredibilitas perusahaan dan loyalitas perusahaan. Selain itu citra perusahaan memiliki efek positif pada kredibilitas perusahaan dan kredibilitas perusahaan memiliki efek positif terhadap loyalitas perusahaan. Demikian juga dengan hasil penelitian yang dilakukan oleh Jennifer Edson Escalas And James R. Bettman (2005) yang menyatakan bahwa citra yang konsisten dalam kelompok referensi meningkatkan citra perusahaan untuk semua konsumen.

Berdasarkan uraian pemikiran dan hasil penelitian tersebut di atas maka diduga bahwa kelompok referensi berpengaruh terhadap citra perusahaan. Begitu juga dengan Nilai yang dirasakan dan Citra perusahaan secara bersamasma diduga berpengaruh terhadap Keputusan Konsumen.

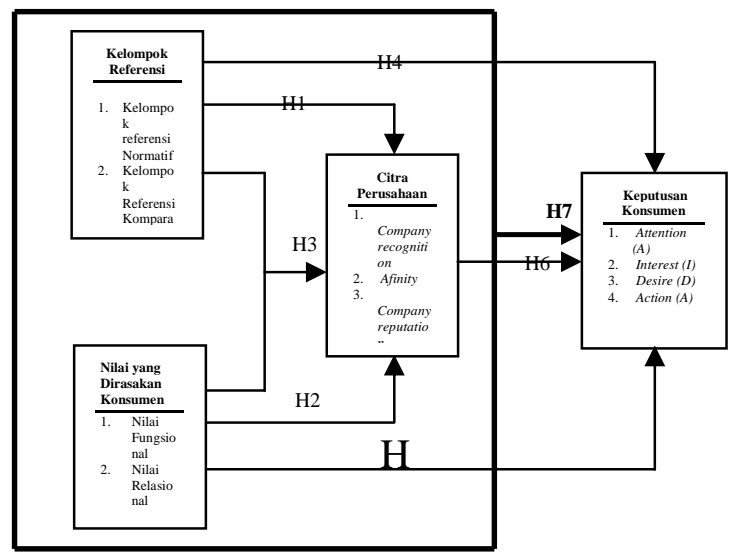

Gambar I. Kerangka Pemikiran

\section{Hipotesis Penelitian}

Berdasarkan deskripsi teori dan kerangka pemikiran yang telah dikemukakan di atas, maka dapat dirumuskan hipotesis penelitian sebagai berikut:

I. Terdapat pengaruh kelompok referensi terhadap citra perusahaan pada asuransi umum di Provinsi DKI Jakarta.

2. Terdapat pengaruh nilai yang dirasakan konsumen terhadap citra perusahaan pada asuransi umum di Provinsi DKI Jakarta.

3. Terdapat pengaruh kelompok referensi dan nilai yang dirasakan konsumen secara bersama-sama terhadap citra perusahaan pada asuransi umum di Provinsi DKI Jakarta.

4. Terdapat pengaruh kelompok referensi terhadap keputusan pembelian pada asuransi umum di Provinsi DKI Jakarta.

5. Terdapat pengaruh nilai yang dirasakan konsumen terhadap keputusan pembelian pada asuransi umum di Provinsi DKI Jakarta.
6. Terdapat pengaruh citra perusahaan terhadap keputusan pembelian pada asuransi umum di Provinsi DKI Jakarta.

7. Terdapat pengaruh kelompok referensi, nilai yang dirasakan konsumen dan citra perusahaan secara bersama-sama terhadap keputusan pembelian pada asuransi umum di Provinsi DKI Jakarta.

\section{METODOLOGI PENELITIAN}

Objek penelitian yang menjadi variabel bebas dalam penelitian ini adalah kelompok referensi dan nilai yang dirasakan.Sedangkan yang menjadi variabel terikat adalah citra perusahaan dan keputusan pembelian.

Sifat penelitian ini adalah bersifat deskriptif dan verifikatif. Unit analisis dalam penelitian ini adalah perusahaan asuransi umum di Provinsi DKI Jakarta,sebanyak 15 perusahaan asuransi umum dengan unit observasi adalah para pelanggan dengan umur polis maksimum satu tahun. Time horizon dalam penelitian ini adalah crossectional, dimana penelitian dilakukan dalam satu waktu secara serentak.

\section{Rancangan Uji Validitas}

Zainal Arifin (20II: 245) berpendapat "validitas adalah suatu derajat ketepatan instrumen (alat ukur), maksudnya apakah instrumen yang digunakan betul-betul tepat mengukur apa yang akan diukur".

Sedangkan kriteria uji validitas Menurut Sugiyono, bila validitas tiap faktor tersebut positif dan besarnya 0,3 ke atas, maka faktor tersebut merupakan construct yang kuat atau valid (Sugiyono,2010:126)

\section{Rancangan Uji Reliabilitas}

Uji ini dilakukan untuk mengetahui tingkat konsistensi hasil pengukuran jika dilakukan pengukuran ulang terhadap gejala dan alat ukur yang sama. Yang dimaksud dengan reliabilitas adalah menunjukan pada suatu pengertian bahwa sesuatu instrumen cukup dapat dipercaya untuk digunakan sebagai alat pengumpulan data karena instrumen tersebut sudah baik. Reliabilitas menunjukan tingkat keterandalan tertentu.Reliabel artinya, dapat dipercaya, jadi dapat diandalkan. (Arikunto, Suharsimi, 2002:154), Pengujian reliabilitas adalah dengan kriteria jika nilai reliabilitas alpha lebih besar dari 0,7 maka instrument dapat dinyatakan reliable

\section{Rancangan Analisis dan Uji Hipotesis}

Berdasarkan tujuan penelitian ini yaitu mengukur pengaruh dari variabel independen 
(kelompok referensi dan nilai yang dirasakan pelanggan) terhadap variabel dependen (keputusan pembelian), melibatkan variabel intervening (citra perusahaan), maka pendekatan dalam pemodelan serta teknik solusi yang digunakan sebagai alat analisis (tool analysis) di dalam disertasi ini adalah dengan menggunakan Structural Equation Model (SEM). Alasan pemilihan metode ini adalah kemampuannya dalam mengukur konstruk secara tidak langsung, yaitu melalui indikator-indikatornya serta sekaligus menganalisis variabel indikator dan variabel laten.

Analisis Structural Equation Model akan memberikan gambaran kejelasan hubungan dan besarnya pengaruh antara variabel penelitian yang sangat berguna untuk mengupas secara terinci berbagai faktor yang mampu meningkatkan nilai pelanggan dan keputusan pembelian. Metode penelitian yang akan digunakan dalam penelitian ini, sesuai dengan tujuan penelitian.

Secara skematik model hubungan antar variabel digambarkan sebagai berikut:

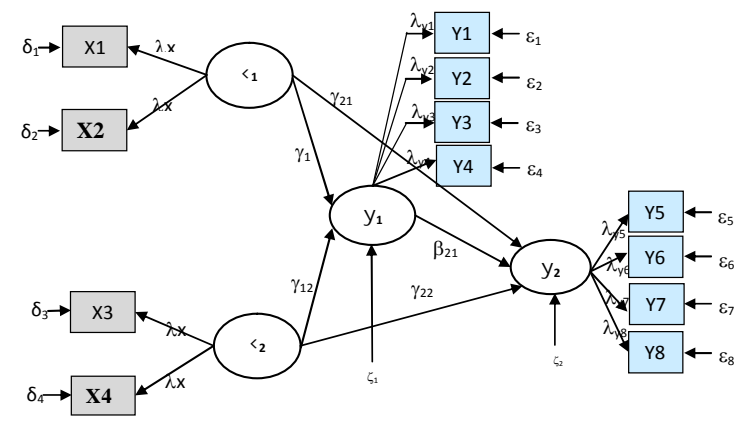

Gambar 2. Model Hubungan Antar variabel

Setelah diagram jalur lengkap berhasil dibuat, maka langkah selanjutnya adalah mengkonversi diagram jalur ke dalam bentuk persamaan, yaitu pengukuran untuk variabel laten eksogen, persamaan pengukuran untuk variabel laten endogen, dan persamaan struktural.

Berpegang pada pedoman tersebut, serta konvensi sebagaimana dikemukakan di atas dapat dikemukakan tiga persamaan umum dalam SEM, sebagai berikut:

I. Persamaan Model Pengukuran Variabel Laten Eksogen, disebut X-Measurement Relationships atau $\mathrm{X}$-model dinyatakan sebagai:

$X_{p}=\lambda(x) p m ~ \xi m+\delta p ;$ Asumsi: $\delta p$ dengan $\xi \mathrm{m}$ tidak berkorelasi.

2. Persamaan model pengukuran variabel laten endogen disebut Y-Measurement
Relationship atau Y-model dinyatakan sebagai berikut:

$Y_{p}=\lambda(y)_{q n} \eta_{n}+\varepsilon_{q} ;$ Asumsi: $\varepsilon_{q}$ dengan $\eta_{n}$ tidak berkorelasi.

3. Persamaan Model Struktural antar variabel laten disebut sebagai structural model dinyatakan sebagai:

$\eta_{\mathrm{n}}=\gamma_{\mathrm{mm}} \xi_{\mathrm{m}}+\beta_{\mathrm{n} n} \eta_{\mathrm{n}}+\zeta_{\mathrm{n}} ;$ Asumsi: $\zeta_{\mathrm{n}}$ dengan $\xi_{\mathrm{m}}$ dan $\eta_{\mathrm{n}}$ tidak berkorelasi.

Uji kesesuaian model dilakukan dengan menggunakan beberapa ukuran kesesuaian model (Goodness of Fit Test, GOF). Pada dasarnya ukuran GOF ini terdiri dari tiga, yaitu ukuran yang bersifat absolut, komparatif, dan parsimoni.

Interpretasi model bertujuan untuk menjawab masalah penelitian yang dajukan. Interpretasi hasil dilakukan berdasarkan keluaran program Lisrel yang meliputi:

I. Diagram jalur

2. Keluaran komputasi statistik model pengukuran

3. Keluaran komputasi statistik model struktural

4. Dekomposisi pengaruh antarvariabel

Karena keluaran program Lisrel relatif banyak, maka untuk memudahkan dalam membuat interpretasi hasil, keluaran tersebut harus diringkas.Tabel Ringkasan Uji Kesesuaian Model

Tabel 3.Rancangan Uji Kesesuaian Model

\begin{tabular}{|c|c|c|}
\hline Ukuran GOF & Estimasi & Hasil Uji \\
\hline RMSEA & $\begin{array}{c}\text { RMSEA }< \\
0.08\end{array}$ & $\begin{array}{c}\text { Good/ Marginal/ } \\
\text { Bad Fit }\end{array}$ \\
\hline GFI & GFI $>0.90$ & $\begin{array}{c}\text { Good/ Marginal/ } \\
\text { Bad Fit }\end{array}$ \\
\hline NNFI & NNFI $>0,90$ & $\begin{array}{c}\text { Good/ Marginal/ } \\
\text { Bad Fit }\end{array}$ \\
\hline NFI & NFI $>0,90$ & $\begin{array}{c}\text { Good/ Marginal/ } \\
\text { Bad Fit }\end{array}$ \\
\hline AGFI & AGFI $>0,90$ & $\begin{array}{c}\text { Good/ Marginal/ } \\
\text { Bad Fit }\end{array}$ \\
\hline RFI & RFI $>0,90$ & $\begin{array}{c}\text { Good/ Marginal/ } \\
\text { Bad Fit }\end{array}$ \\
\hline IFI & IFI $>0,90$ & $\begin{array}{c}\text { Good/ Marginal/ } \\
\text { Bad Fit }\end{array}$ \\
\hline
\end{tabular}

\section{HASIL PENELITIAN DAN PEMBAHASAN}

\section{Hasil Uji Validitas dan Reliabilitas}

Hasil pengujian validitas setiap pertanyaan pada kuesioner untuk setiap variabel dengan $r>0,3$ (Sugiyono, 2004:329), maka menunjukkan bahwa semua pertanyaan mempunyai nilai korelasi yang lebih besar dari 
0,3. Hal ini berarti semua pertanyaan adalah valid.

\section{Hasil Uji Reliabilitas Variabel}

Uji reliabilitas dengan Cronbach Alpha, maka setiap variabel memperoleh nilai Cronbach Alpha> 0,7 (Arikunto, 2002:I7I) artinya hasil instrument dapat dikatakan reliabel. Berdasarkan hasil uji ternyata semua variabel memiliki nilai Cronbach Alpha 0,7 sehingga semua variabel dapat dikatakan reliabel, sebagaimana yang terlihat pada Tabel 5.I

Tabel 4.Uji Reliabilitas untuk Variabel Penelitian $(n=30)$

\begin{tabular}{|l|c|c|}
\hline \multicolumn{1}{|c|}{ Variabel } & $\begin{array}{c}\text { Nilai } \\
\text { Cronbach } \\
\text { Alpha }\end{array}$ & Kesimpulan \\
\hline $\begin{array}{l}\text { Kelompok } \\
\text { Referensi }\end{array}$ & 0,744 & Reliabel \\
\hline $\begin{array}{l}\text { Nilai Yang } \\
\text { Dirasakan }\end{array}$ & 0,761 & Reliabel \\
\hline $\begin{array}{l}\text { Citra Perusahaan } \\
\text { Keputusan } \\
\text { Pembelian }\end{array}$ & 0,747 & Reliabel \\
\hline
\end{tabular}

Sumber : Hasil Pengolahan SPSS 17.002015

\section{Analisis Data}

\section{Analisis Model Pengukuran}

Analisis model pengukuran dilakukan dengan tujuan untuk melihat validitas dan reliabilitas setiap konstruk yang membangun model penelitian. Pengukuran validitas konstruk dilakukan dengan menggunakan prosedur Confirmatory Factor Analysis (CFA) (Anderson \& Gerbing, 1979). Melalui CFA ini, akan diseleksi indikator atau variabel teramati yang akan membentuk konstruk. Dalam perseleksian tersebut, digunakan dua kriteria, yaitu variabel tersebut harus memiliki Standardized Loading Factor (SLF) $\geq 0,7$ dan atau nilai $|t| \geq 1,96$ (pada $\alpha=0,05)$ (Wijanto, 2008). Berkaitan dengan SLF, adapula yang memberikan kriteria berbeda, yaitu Igbaria et al. (2005), yang menyarankan bahwa SLF dengan nilai $\geq 0,50$ masih dapat digunakan.

Sementara itu, reliabilitas konstruk diukur dengan menggunakan dua ukuran (Hair et, al, $2006: 636)$, yaitu :

(I) Composite Reliability Measure atau Construk Reliability Measure (CR), atau sering disebut sebagai reliabilitas, dengan peryaratan nilai CR harus $\geq 0,7$.

(2) Variance Extract Measure (VE) atau ekstrak varian, dengan persyaratan harus memiliki nilai $V E \geq 0,5$.
Pada penelitian ini semua konstruk memiliki format first order, sehingga analisis model pengukuran dilakukan melalui satu tahap pengukuran validitas dan reliabilitas, dimana pada tahap pertama dilakukan first order CFA terhadap konstruk. Hasil analisis data dengan menggunakan metode Structural Equation Model (SEM) dan dengan tool pengolahan software aplikasi LISREL 8.70 makadiperoleh summaryukuran kesesuaian model seperti ditunjukkan pada Tabel 4.2 di bawah ini.

Tabel 5. Ukuran Kesesuaian Model

\begin{tabular}{|c|c|c|c|}
\hline $\begin{array}{c}\text { Indikator } \\
\text { GOF }\end{array}$ & $\begin{array}{c}\text { Ukuran } \\
\text { yang } \\
\text { Diharapkan }\end{array}$ & $\begin{array}{c}\text { Hasil } \\
\text { Estimasi }\end{array}$ & Kesimpulan \\
\hline \multicolumn{4}{|c|}{ Ukuran Absolute Fit } \\
\hline GFI & $\begin{array}{l}\text { GFI } \\
0,90\end{array}$ & 0,94 & Good Fit \\
\hline RMSEA & $\begin{array}{l}\text { RMSEA } \\
<0,08\end{array}$ & 0,075 & Good Fit \\
\hline \multicolumn{4}{|c|}{ Ukuran Incremental Fit } \\
\hline NNFI & $\begin{array}{l}\text { NNFI > } \\
0,90\end{array}$ & 0,98 & Good Fit \\
\hline $\mathrm{NFI}$ & $\begin{array}{l}\mathrm{NFI} \\
0,90\end{array}$ & 0,98 & Good Fit \\
\hline AGFI & $\begin{array}{l}\text { AGFI > } \\
0,90\end{array}$ & 0,89 & Good Fit \\
\hline RFI & $\begin{array}{ll}\text { RFI } & > \\
0,90 & \end{array}$ & 0,98 & Good Fit \\
\hline IFI & $\begin{array}{l}\mathrm{IFI} \\
0,90\end{array}$ & 0,99 & Good Fit \\
\hline CFI & $\begin{array}{ll}\mathrm{CFI} & > \\
0,90 & \end{array}$ & 0,99 & Good Fit \\
\hline
\end{tabular}

Sumber : Hasil Pengolahan dengan LISREL 8.70

Berdasarkan Tabel 4.2 di atas, semua ukuran kesesuaian model yang diperoleh memiliki indeks kesesuaian model yang baik (good fit), dengan demikian maka dapat dilanjutkan pada analisis berikutnya.

Model penuh persamaan SEM dengan menggunakan program LISREL 8.70 diperoleh dua model diagram lintasan, yiatu model standardized dan model t-values,masing-masing model seperti ditunjukkan pada Gambar

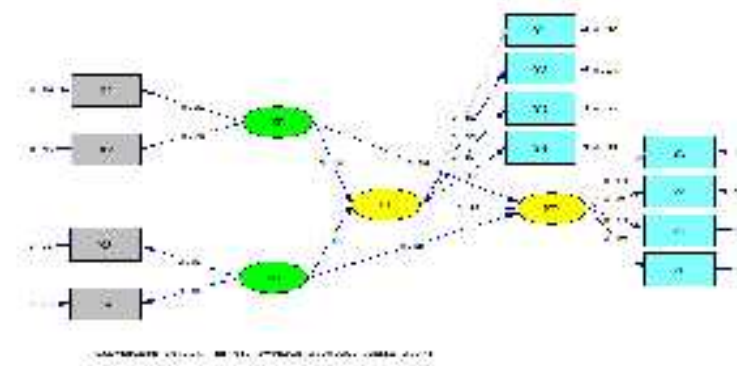

Gambar 3.Full SEM (Standardized Model) 


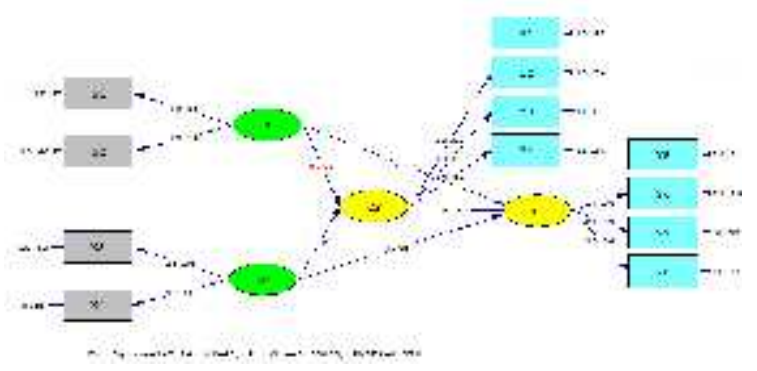

Gambar 4.Full SEM (t-value model)

Dimana:

$\mathrm{KR}=$ Kelompok Referensi

$N D=$ Nilai Yang Dirasakan Pelanggan

$\mathrm{CP}=$ Citra Perusahaan

$\mathrm{KP}=$ Keputusan Pembelian Konsumen

Berdasarkan Gambar 3 dan Gambar 4 di atas, selanjutnya adalah melakukan analisis model pengukuran full model SEM dari setiap variabel, seperti ditunjukkan pada Tabel 5.II di bawah ini.

Tabel6.Confirmatory Factor Analysis (CFA)Full Model SEM

\begin{tabular}{|c|c|c|c|c|c|c|}
\hline \multicolumn{2}{|c|}{ Model Pengukuran } & \multirow{2}{*}{$\begin{array}{c}\text { Standart } \\
\text { Loading } \\
\text { Factor }\end{array}$} & \multirow{2}{*}{$\begin{array}{c}\text { Standard } \\
\text { Error (SE) }\end{array}$} & \multirow[b]{2}{*}{ Nilai $t_{\text {hitung }}$} & \multirow{2}{*}{$\begin{array}{c}\text { Construk } \\
\text { Reliability } \\
\text { (CR) }\end{array}$} & \multirow{2}{*}{$\begin{array}{c}\text { Variance } \\
\text { Extract } \\
(V E)\end{array}$} \\
\hline $\begin{array}{c}\text { Variabel } \\
\text { laten }\end{array}$ & \begin{tabular}{|c|} 
Var. \\
Manifes
\end{tabular} & & & & & \\
\hline \multirow[t]{2}{*}{$\begin{array}{c}\text { Kelompok } \\
\text { Referensi } \\
(\xi ।)\end{array}$} & \begin{tabular}{|l|} 
Kelompok \\
Referensi \\
Normatif \\
$(X I)$
\end{tabular} & 0,81 & 0,046 & 16,93 & \multirow{2}{*}{0,9613} & \multirow{2}{*}{0,9256} \\
\hline & \begin{tabular}{|l|} 
Kelompok \\
Referensi \\
Komparatif \\
$(\times 2)$ \\
\end{tabular} & 0,74 & 0,045 & 15,14 & & \\
\hline \multirow{4}{*}{ 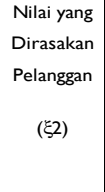 } & Nilai & & & & \multirow{4}{*}{0,9692} & \multirow{4}{*}{0,9403} \\
\hline & Fungsional & 0.81 & 0,046 & 18,06 & & \\
\hline & $(\times 3)$ & & & & & \\
\hline & \begin{tabular}{|l|} 
Nilai \\
Relasional \\
(X4)
\end{tabular} & 0,86 & 0,047 & 19,62 & & \\
\hline \multirow{4}{*}{$\begin{array}{c}\text { Citra } \\
\text { Perusahaan } \\
\qquad \eta I\end{array}$} & $\begin{array}{l}\text { Company } \\
\text { Recognition } \\
(\mathrm{YI}) \\
\end{array}$ & 0,84 & 0,041 & - & \multirow{4}{*}{0,9799} & \multirow{4}{*}{0,942} \\
\hline & $\begin{array}{l}\text { Afinity } \\
\text { (Y2) }\end{array}$ & 0.86 & 0,04 & 20,02 & & \\
\hline & $\begin{array}{l}\text { Company } \\
\text { Reputation } \\
(\mathrm{Y} 3) \\
\end{array}$ & 0,83 & 0,042 & 19,07 & & \\
\hline & $\begin{array}{l}\text { Domain } \\
\text { (Y4) }\end{array}$ & 0,83 & 0,04 & 18,94 & & \\
\hline \multirow{2}{*}{$\begin{array}{c}\text { Keputusan } \\
\text { Pembelian } \\
\text { Konsumen } \\
\text { dalam }\end{array}$} & $\begin{array}{l}\text { Attention } \\
\text { (Y5) }\end{array}$ & 0,83 & - & - & \multirow{4}{*}{0,9807} & \multirow{4}{*}{0,9443} \\
\hline & Interest $(Y 6)$ & 0,81 & 0,063 & 17,94 & & \\
\hline \multirow{2}{*}{$\begin{array}{c}\text { Asuransi } \\
(\eta 2)\end{array}$} & Desire (Y7) & 0,9 & 0,066 & 21,09 & & \\
\hline & Action (Y8) & 0,87 & 0,062 & 20,04 & & \\
\hline
\end{tabular}

Sumber : Hasil pengolahan LISREL 8.70

Catatan : Kriteria CR dan VE adalah (Hair, Andersen, Tatham, dan Black, 2006 :636):

a. Composite Reliability Measure atau Construk Reliability Measure $(C R)$, atau sering disebut sebagai reliabilitas, dengan peryaratan nilai $C R$ harus $\geq 0,7$.

b. Variance Extract Measure (VE) atau ekstrak varian, dengan persyaratan harus memiliki nilai $V E \geq 0,5$.

Berdasarkan Tabel 6diketahui semua sub variabel (dimensi) dalam pembentukan variabel laten eksogen Kelompok Referensi dan Nilai Yang Dirasakan, maupun variabel laten endogen Citra Perusahaan dan Keputusan Pembelian memiliki validitas yang baik, hal ini ditunjukkan dengan semua sub variabel memiliki Standardized Loading Factor (SLF) $\geq 0,5$ dan atau nilai thitung $\geq$ I,96 (pada $\alpha=0,05$ ) (Hair, et.al., 2006). Demikian juga baik variabel laten eksogen maupun endogen memiliki reliabilitas model yang baik, hal ditunjukkan dengan semuanya variabel memiliki nilai construct reliability yang lebih besar dari $0,70(C R>0,70)$ dan nilai variance extract yang lebih besar dari 0,50 (VE > $0,50)$.

\section{Analisis Model Struktural}

Analisis model struktural dilakukan dengan tujuan untuk mengkaji hubungan antar variabel laten (Latent Variabel atau LV) yang ada di dalam model penelitian. Pengkajian ini sekaligus menguji berbagai hipotesis yang diajukan dan telah dijelaskan pada bab sebelumnya. Ada dua bentuk pengujian yang dilakukan dalam analisis model struktural yaitu uji Kesesuaian keseluruhan model dan uji Kesesuaikan model struktural.

Berdasarkan hasil uji semua ukuran kesesuaian model yang diperoleh memiliki indeks kesesuaian model yang baik (good fit), dengan demikian maka dapat dilanjutkan pada analisis berikutnya.

Kemudian berdasarkan hasil analisis dengan Lisrel 8.70 didapatkan model persamaan struktural secara keseluruhan yang terlihat pada Gambar 7 berikut.

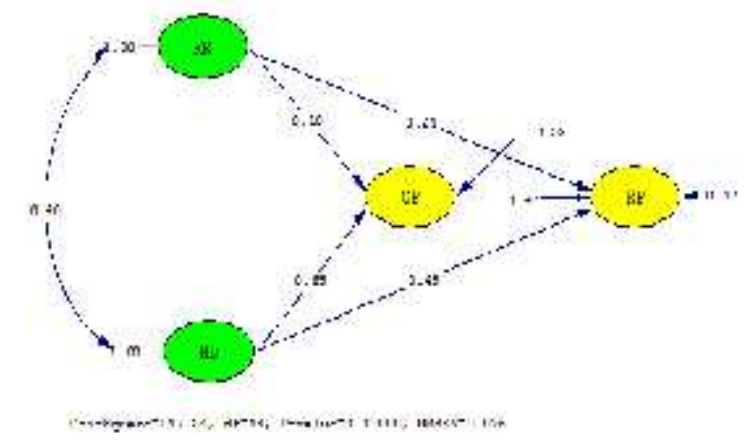

Gambar 7. Model Persamaan Struktural secara Keseluruhan (Standardized) 


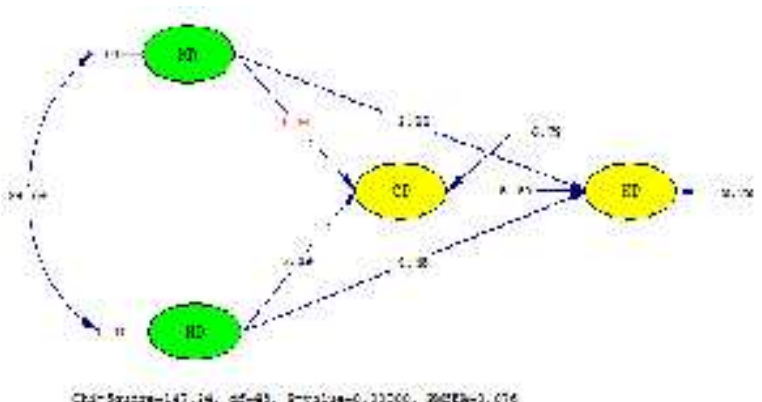

Gambar 8.Model Persamaan Struktural secara Keseluruhan (t-value)

Berdasarkan Gambar 8 dapat diketahui adanya hubungan antara variabel bebas dengan variabel terikat. Hasil dari pengujian signifikansi dari hubungan antar variabel laten, atau lintasan antara dua variabel laten, dapat dilihat pada Tabel 7 di bawah. Pada tabel 7diperlihatkan nilai koefisien yang dihasilkan beserta nilai $t_{\text {hitung }}$ dan $F_{\text {hitung. }}$. Apabila lintasan struktural memiliki nilai $t_{\text {hitung }} \geq$ I,96, maka koefisien dari lintasan tersebut dinyatakan signifikan, dan apabila $t_{\text {hitung }}$ $<$ 1,96, maka disimpulkan bahwa koefisien dari lintasan tidak signifikan. Sementara Apabila lintasan struktural secara bersama-sama memiliki nilai $F_{\text {hitung }} \geq 3,84$, maka koefisien dari lintasan tersebut dinyatakan signifikan, dan apabila $F_{\text {hitung }}<3,84$, maka disimpulkan bahwa koefisien dari lintasan tidak signifikan.

Tabel7. Uji Kesesuaian Hubungan Antar Variabel

\begin{tabular}{|c|c|c|c|c|c|}
\hline No & $\begin{array}{l}\text { Lintasan } \\
\text { Struktur }\end{array}$ & SLF & $\begin{array}{l}t_{\text {hitung }} \\
\text { /F } \\
\text { hitung }\end{array}$ & \begin{tabular}{|c|}
$t_{\text {tabel }}$ \\
IF \\
tabel
\end{tabular} & Hasil Uji \\
\hline 1 & $\begin{array}{l}\text { Kelompok } \\
\text { Referensi } \\
(K R) \rightarrow \text { Citra } \\
\text { Perusahaan (CP) }\end{array}$ & 0,1 & 0,64 & 1,96 & $\begin{array}{c}\text { Tidak } \\
\text { Signifikan }\end{array}$ \\
\hline 2 & $\begin{array}{l}\text { Nilai Yang } \\
\text { Dirasakan } \\
\text { Pelanggan (ND) } \\
\rightarrow \text { Citra } \\
\text { Perusahaan (CP) }\end{array}$ & 0,65 & 7,19 & 1,96 & Signifikan \\
\hline 3 & $\begin{array}{l}\text { Kelompok } \\
\text { Referensi } \\
\text { (KR) dan Nilai } \\
\text { Yang Dirasakan } \\
\text { Pelanggan (ND) } \\
\rightarrow \text { Citra } \\
\text { Perusahaan (CP) }\end{array}$ & 0,48 & 109,02 & 3,84 & Signifikan \\
\hline 4 & $\begin{array}{l}\text { Kelompok } \\
\text { Referensi } \\
(K R) \rightarrow \text { Keputusa } \\
n \text { Pembelian } \\
(K P)\end{array}$ & 0,24 & 2.84 & 1,96 & Signifikan \\
\hline 5 & $\begin{array}{l}\text { Nilai Yang } \\
\text { Dirasakan } \\
\text { Pelanggan (ND) } \\
\rightarrow \text { Keputusan } \\
\text { Pembelian (KP) }\end{array}$ & 0,45 & 3.72 & 1,96 & Signifikan \\
\hline 6 & $\begin{array}{l}\text { Citra } \\
\text { Perusahaan } \\
(C P) \rightarrow \text { Keputusa } \\
n \text { Pembelian } \\
(K P)\end{array}$ & 0,47 & 1.98 & 1,96 & Signifikan \\
\hline 7 & $\begin{array}{l}\text { Kelompok } \\
\text { Referensi (KR), } \\
\text { Nilai Yang } \\
\text { Dirasakan } \\
\text { Pelanggan (ND), } \\
\text { dan Citra } \\
\text { Perusahaan } \\
(C P) \\
\rightarrow \text { Keputusan } \\
\text { Pembelian }(K P)\end{array}$ & 0,83 & 388,92 & 3,84 & Signifikan \\
\hline
\end{tabular}


Kelompok Referensi dan Nilai Yang Dirasakan konsumen berpengaruh terhadap Citra Perusahaan.

Pada bagian ini akan dilakukan pengujian hipotesis tentang pengaruh antara variabel eksogen Kelompok Referensi $\left(\xi_{1}\right)$ dan Nilai Yang Dirasakan $\left(\xi_{2}\right)$ terhadap variabelendogen Citra Perusahaan $\left(\eta_{1}\right)$ baik secara parsial maupun bersama-sama. Hasil yang diperoleh dengan menggunakan program LISREL 8.70 untuk model persamaan struktural, sesuai dengan hipotesis yang diajukan adalah :

$\mathrm{CP}=0.10 * \mathrm{KR}+0.65 * \mathrm{ND}$, Errorvar. $=0.52, \mathrm{R}^{2}$ $=0.48$
$(0.16)$
$(0.090)$
$0.64 \quad 7.19$
$(0.077)$
6.73109 .02

$(0.004)$

(Sumber : Lampiran output LISREL 8.70)

Berdasarkan persamaan struktural $4.4 \mathrm{di}$ atas, terlihat besarnya loading factor (koefisien jalur) variabel Kelompok Referensi terhadap Citra Perusahaan adalah sebesar 0,10 danbesarnya loading factor (koefisien jalur) variabel Nilai Yang Dirasakan Pelanggan terhadapCitra Perusahaanadalah sebesar 0,65. Dengan demikian hubungan variabel Kelompok Referensi, Nilai Yang Dirasakan Pelanggandan Citra Perusahaansecara model struktural dapat dilihat pada gambar 4.5 di bawah.

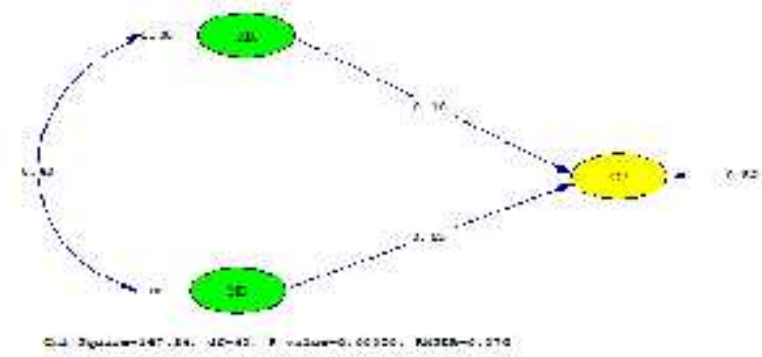

\section{Gambar 9.Sub Model Struktural I} (Standardize)

Berdasarkan Gambar 9 nilai thitung dan nilai Fhitung untuk menguji hipotesis I, 2, dan 3 adalah sebagai berikut :

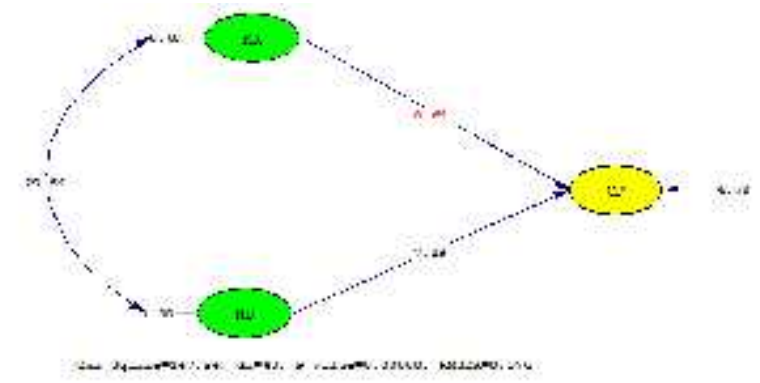

Gambar I0.Sub Model Struktural I (tvalue)
Pengaruh Kelompok Referensi dan Nilai yang Dirasakan Pelanggan terhadap Citra Perusahaan

\section{Kelompok Referensi Berpengaruh terhadap Citra Perusahaan}

Dari hasil perhitungan didapat sebesar $0,64<1,96$, sehingga dapat dikatakan tidak signifikan, jadi secara parsial Kelompok Referensi berpengaruh tidak signifikan terhadap Citra Perusahaan, maka dengan demikian Hipotesis I ditolak. Hasil pengujian hipotesis ini menunjukkan bahwa Kelompok Referensi yang diukur dengan Kelompok Normatif dan Kelompok Komparatif secara parsial berpengaruh tidak signifikan.

\section{Nilai Yang Dirasakan Konsumen Berpengaruh terhadap Citra Perusahaan \\ Berdasarkan persamaan di atas,} ternyata nilai thitung dari pengaruh Nilai Yang Dirasakan Pelanggan terhadap Citra Perusahaan adalah sebesar $7,19>1,96$, sehingga dapat dikatakan signifikan, jadi secara parsial Nilai Yang Dirasakan Pelanggan berpengaruh signifikan terhadap Citra Perusahaan, maka dengan demikian Hipotesis 2 diterima.

\section{Kelompok Referensi dan Nilai Yang Dirasakan Konsumen Berpengaruh terhadap Citra Perusahaan}

Berdasarkan persamaan di atas, ternyata nilai $F_{\text {hitung }}$ dari pengaruh Kelompok Referensi dan Nilai Yang Dirasakan Pelanggan terhadapCitra Perusahaan adalah sebesar 109,02>3,84 dengan nilai koefisien determinan $\left(R^{2}\right)$ sebesar 0,48 , sehingga dapat dikatakan signifikan. Hal ini menunjukkan bahwa secara bersama-sama Kelompok Referensi dan Nilai Yang Dirasakan Pelanggan berpengaruh signifikan terhadap Citra Perusahaan, maka dengan demikian Hipotesis 3 diterima.

\section{Kelomok Referensi, Nilai Yang Dirasakan Konsumen, dan Citra Perusahaan , berpengaruh terhadap Keputusan Pembelian.}

Pada bagian ini akan dilakukan pengujian hipotesis tentang pengaruh antara variabel eksogen Kelompok Referensi $\left(\xi_{1}\right)$, Nilai Yang Dirasakan $\left(\xi_{2}\right)$, dan variabel endogen Citra Perusahaan $\left(\eta_{1}\right)$ terhadap variabel endogen Keputusan Pembelian $\left(\eta_{2}\right)$ baik secara parsial maupun bersama-sama. Hasil yang diperoleh 
dengan menggunakan program LISREL 8.70 untuk model persamaan struktural, sesuai dengan hipotesis yang diajukan adalah :

$\mathrm{KP}=0.47 * \mathrm{CP}+0.24 * \mathrm{KR}+0.45 * \mathrm{ND}$

Errorvar. $=0.17, \mathrm{R}^{2}=0.83$
$(0.074)$
$(0.101)$
$(0.046)$

$$
5.80
$$

388.92

(Sumber : Lampiran output LISREL 8.70)

Berdasarkan persamaan strukturaldi atas, terlihat besarnya loading factor (koefisien jalur) variabel Kelompok Referensi terhadap Keputusan Pembelian adalah sebesar 0,24, besarnya loading factor (koefisien jalur) variabel Nilai Yang Dirasakan terhadap Keputusan Pembeliansebesar 0,45, dan besarnya loading factor (koefisien jalur) variabel Citra Perusahaan terhadapkeputusan Pembelian adalah sebesar 0,47 . Dengan demikian hubungan variabel Kelompok Referensi, Nilai Yang Dirasakan Pelanggan, Citra Perusahaan, dan Keputusan Pembeliansecara model struktural dapat dilihat pada gambar 5.6 di bawah.

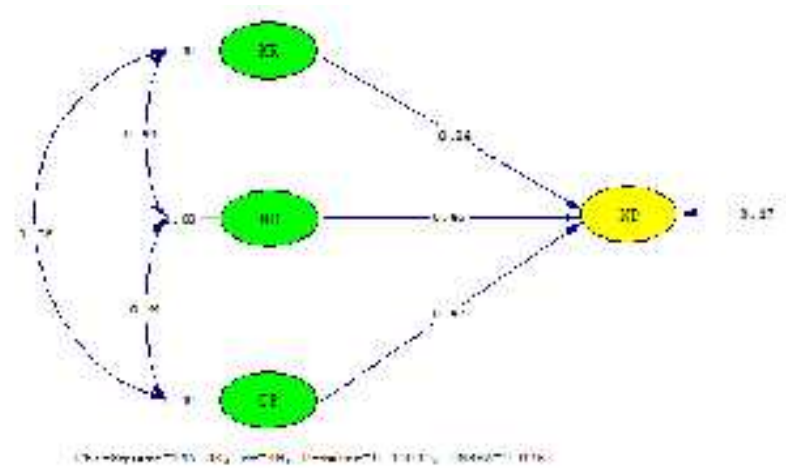

Gambar I I. Sub Model Struktural I (Standardize)Pengaruh Kelompok Referensi, Nilai Yang Dirasakan Konsumen, dan Citra Perusahaan terhadap Keputusan Pembelian

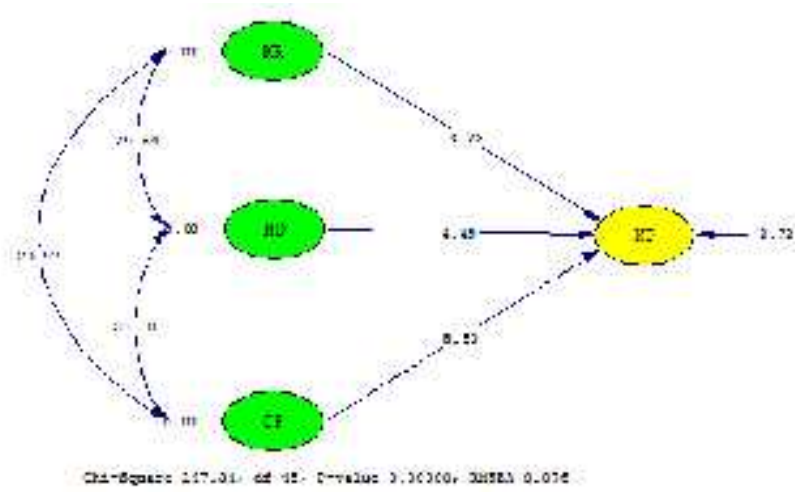

Gambar I 2.Sub Model Struktural I

(t-value)
Pengaruh Kelompok Referensi, Nilai Yang Dirasakan Konsumen, dan Citra Perusahaan terhadap Keputusan Pembelian

I. Kelompok Referensi Berpengaruh terhadap Keputusan Pembelian

Berdasarkan persamaan di atas, ternyata nilai $t_{\text {hitung }}$ dari pengaruh Kelompok Referensi terhadap Keputusan Pembelian adalah sebesar $3,22>1,96$, sehingga dapat dikatakan signifikan, atau secara parsial Kelompok Referensi berpengaruh signifikan terhadap Keputusan Pembelian, maka dengan demikian Hipotesis 4 diterima.

2. Nilai Yang Dirasakan KonsumenBerpengaruh terhadap Keputusan Pembelian

Berdasarkan persamaan di atas, ternyata nilai $t_{\text {hitung }}$ dari pengaruh Nilai Yang Dirasakan Pelangganterhadap Keputusan Pembelian adalah sebesar 4,45>1,96, sehingga dapat dikatakan signifikan, jadi secara parsial Nilai Yang Dirasakan Pelanggan berpengaruh signifikan terhadap Keputusan Pembelian, maka dengan demikian Hipotesis 5 diterima.

3. Citra PerusahaanBerpengaruh terhadap Keputusan Pembelian

Berdasarkan persamaan di atas, ternyata nilai thitung dari pengaruh Citra Perusahaanterhadap Keputusan Pembelian adalah sebesar 5,80>1,96, sehingga dapat dikatakan signifikan, jadi secara parsial Citra Perusahaanberpengaruh signifikan terhadap Keputusan Pembelian, maka dengan demikian Hipotesis 6 diterima.

4. Kelompok Referensi, Nilai Yang Dirasakan Konsumen, dan Citra Perusahaan secara Bersama-sama Berpengaruh terhadap Keputusan Pembelian

Berdasarkan persamaan di atas, ternyata nilai $F_{\text {hitung }}$ dari pengaruh Kelompok Referensi, Nilai Yang Dirasakan Pelanggan, dan Citra Perusahaan terhadapKeputusan Pembelian adalah sebesar 388,92>3,84 dengan nilai koefisien determinan $\left(R^{2}\right)$ sebesar 0,83 , sehingga dapat dikatakan signifikan. Hal ini menunjukkan bahwa secara bersama-sama Kelompok Referensi, Nilai Yang Dirasakan Pelanggan, dan Citra Perusahaan berpengaruh signifikan terhadap Keputusan Pembelian, maka dEngan demikian Hipotesis 7 diterima. 


\section{PENUTUP}

\section{Kesimpulan}

Penelitian ini dimaksudkan untuk mencari faktor-faktor yang mempengaruhi Keputusan Pembelian Konsumen dalam memilih Asuransi Umum di DKI Jakarta. Penelitian ini menggunakan metode survei, yang bertujuan untuk mengetahui gambaran umum tentang pengaruh Kelompok Referensi dan Nilai Yang Dirasakan terhadap Citra Perusahaan serta implikasinya pada Keputusan Pembelian. Berdasarkan hasil penelitian ini dapat disimpulkan sebagai berikut.

I. Kelompok referensi secara parsial berpengaruh positif tidak signifikan terhadap Citra Perusahaan, artinya bahwa peningkatan Kelompok Referensi pada Perusahaan Asuransi Umum di DKI Jakarta tidak akan mengakibatkan meningkatnya Citra Perusahaan Asuransi Umum di DKI Jakarta.

2. Nilai yang dirasakan konsumen secara parsial berpengaruh positif dan signifikan terhadap Citra Perusahaan, dan Dimensi paling dominan dalam membentuk variabel Nilai Yang Dirasakan Konsumen adalah dimensi Nilai Relasional

3. Kelompok Referensi dan Nilai Yang Dirasakan Pelanggan secara bersama-sama berpengaruh positif dan signifikan terhadap Citra Perusahaan Asuransi Umum di DKI Jakarta dengan nilai koefisien determinasi $\left(R^{2}\right)$ sebesar $48 \%$.

4. Kelompok Referensi secara parsial berpengaruh positif dan signifikan terhadap Keputusan Pembelian. Dimensi yang paling dominan dalam membentuk variabel Kelompok Referensi adalah dimensi Kelompok Referensi Normatif terutama pada indikator tingkat persamaan usia, ras, jenis kelamin, Authoritative, Permissive, dan Neglecting-rejecting.

5. Nilai yang dirasakan pelanggan secara parsial berpengaruh positif dan signifikan terhadap Keputusan Pembelian, artinya bahwa peningkatan nilai yang dirasakan pelanggan akan mengakibatkan meningkatnya Keputusan Pembelian pada Perusahaan Asuransi Umum di DKI Jakarta. Dimensi paling dominan dalam membentuk variabel nilai yang dirasakan konsumen adalah dimensi nilai relasional.

6. Citra Perusahaan secara parsial berpengaruh positif dan signifikan terhadap Keputusan Pembelian, artinya bahwa peningkatan Citra Perusahaan Asuransi
Umum akan mengakibatkan meningkatnya Keputusan Pembelian pada Perusahaan Asuransi Umum di DKI Jakarta. Dimensi paling dominan dalam membentuk variabel citra perusahaan adalah dimensi afinity terutama pada indikator tingkat ketertarikan pelanggan atas kualitas layanan asuransi.

7. Kelompok Referensi, Nilai Yang Dirasakan Pelanggan, dan Citra Perusahaan secara bersama-sama berpengaruh positif dan signifikan terhadap Keputusan Pembelian pada Asuransi Umum di DKI Jakarta dengan nilai koefisien determinasi $\left(R^{2}\right)$ sebesar $83 \%$, hal ini menunjukkan bahwa 83\% variabel Keputusan Pembelian terutama pada dimensi disire

\section{Implikasi Teoritis}

Berdasarkan hasil penelitian di atas, diperoleh temuan dari penelitian ini adalah bahwa untuk meningkatkan keputusan pembelian konsumen pada Polis Asuransi Umum di DKI Jakarta terutama pada dimensi desireakan mampu ditingkatkan jika Perusahaan Asuransi Umum mampu meningkatkan citra perusahaan asuransi umum terutama pada dimensi afinity, dimana citra perusahaan asuransi umum akan mampu ditingkatkan apabila Perusahaan Asuransi Umum mampu meningkat nilai yang dirasakan konsumenterutama pada unsur nilai relasional serta didukung dengan meningkat kelompok referensi terutama pada unsur kelompok referensi normatif

\section{Implikasi Manajerial}

Citra Perusahaan pada Asuransi Umum di DKI Jakarta terutama dalam dimensi afinity akan mampu ditingkatkan jika Perusahaan Asuransi Umum di DKI Jakarta mampu meningkatkan Nilai Yang Dirasakan pelanggan terutama pada dimensi Nilai Relasional, serta didukung dengan meningkatkan Kelompok Referensi terutama pada dimensi Kelompok Referensi Normatif.

Keputusan Pembelian pada Perusahaan Asuransi Umum di DKI Jakarta terutama pada dimensi Desire akan mampu ditingkatkan jika Perusahaan Asuransi Umum di DKI Jakarta mampu meningkatkan Citra Perusahaan terutama pada dimensi Afinity, di mana Citra Perusahaan akan meningkat apabila perusahaan asuransi umum mampu meningkatkan Budaya Organisasai terutama pada dimensi Budaya Birokrasi dan mampu meningkatkan Nilai Yang Dirasakan pelanggan terutama pada dimensi Nilai Relasional, serta didukung dengan 
meningkatkan Kelompok Referensi terutama pada dimensi Kelompok Referensi Normatif.

\section{Saran Manajerial}

Setelah melakukan penelitian ini, berdasarkan penemuan empirik yang diperoleh, maka bagian akhir penulisan disertasi ini, peneliti menyampaikan beberapa saran dalam usaha perbaikan Kelompok Referensi, Nilai Yang Dirasakan Pelanggan, Citra Perusahaan dan Keputusan Pembelian pada Perusahaan Asuransi Umum di DKI Jakarta. Berdasarkan hasil penelitian dan pembahasan maka dapat dikemukakan saran-saran sebagai berikut.

I. Citra Perusahaan Asuransi Umum di DKI Jakarta sudah relatif baik sehingga akan mampu memberikan peningkatan pada Keputusan Pembelian Konsumen pada Asuransi Umum di DKI Jakarta dalam memilih Asuransi Umum. Peningkatan Citra Perusahaan di pengaruhi secara dominan dengan peningkatan Nilai Yang Dirasakan Pelanggan utamanya pada dimensi Nilai Relasional. Beberapa indikator pada Nilai Yang Dirasakan Pelanggan yang disarankan untuk tetap dipertahankan terutama pada dimensi Nilai Yang Dirasakan yaitu pada indikator tingkat kepercayaan, komitmen, kebaikan penanganan konflik, dan kelancaran komunikasi. Namun demikian masih terdapat beberapa indikator pada Nilai Yang Dirasakan pelanggan yang disarankan untuk tetap diperhatikan dan ditingkatkan seperti pada indikator tingkat Ketertarikan perusahaan dalam menyelesaikan masalah pelannggan, Kesesuaian kegiatan dengan jadwal yang dijanjikan, Pemenuhan spesifikasi kebutuhan pelanggan, Ketepatan saran yang diberikan, Kesesuaian biaya dengan pelayanan yang ditawarkan, Kesamaan biaya dengan perusahaan lain yang sejenis, dan Flexibilitas pelayanan pelanggan.

2. Keputusan Pembelian konsumen pada Perusahaan Asuransi Umum di DKI Jakarta sudah relatif tinggi dalam memilih Asuransi Umum. Peningkatan Keputusan Pembelian dipengaruhi secara dominan oleh Citra Perusahaan utamanya pada dimensi Afinity. Beberapa indikator pada Citra Perusahaan yang disarankan untuk tetap dipertahankan terutama pada dimensi Afinity yaitu pada indikator tingkat ketertarikan pelanggan membeli asuransi, ketertarikan pelanggan atas kualitas layanan asuransi, dan ketertarikan pelanggan atas kemudahan-kemudahan dalam mengasuransikan asetnya, serta pada dimensi company recognition, company reputation, dan domain seperti pada indikator tingkat perusahaan dikenal oleh pelanggan sebagai perusahaan asuransi besar, perusahaan dikenal oleh pelanggan sebagai perusahaan asuransi yang dapat dipercaya, perusahaan memiliki agen-agen yang memudahkan pelanggan. Namun demikian masih terdapat beberapa indikator pada Citra Perusahaan yang disarankan untuk diperhatikan dan ditingkatkan oleh Perusahaan Asuransi Umum di DKI Jakarta seperti pada indikator tingkat perusahaan dikenal oleh pelanggan sebagai perusahaan asuransi yang bonafit, perusahaan memiliki reputasi yang baik dalam asuransi, perusahaan selalu memberikan kepastian atas klaim konsumennya, perusahaan selalu memberikan kepuasan konsumennya, perusahaan memiliki merek produk asuransi yang sudah terkenal.

\section{Saran untuk Peneliti Lebih Lanjut}

I. Masih banyak variabel lain yang mempengaruhi Keputusan Pembelian pada Perusahaan Asuransi Umum di DKI Jakarta, seperti marketing mix, relasionship, kualitas pelayanan, kepuasan pelanggan, dan variabel lainnya agar diteliti lebih lanjut, karena mungkin saja ada variabel-variabel lain selain yang ada pada penelitian ini memiliki pengaruh dominan dalam meningkatkan Keputusan Pembelian konsumen.

2. Penelitian ini menggunkan variabel Citra Perusahaan sebagai variabel antara (intervening), sehingga untuk penelitian selanjutnya kemungkinan akan menghasilkan temuan yang berbeda, apabila variabel Citra Perusahaan yang digunakan sebagai variabel moderasi (moderating).

3. Penelitian ini menggunakan variabel Citra Perusahaan sebagai variabel antara (intervening), sehingga untuk penelitian selanjutnya kemungkinan akan menghasilkan temuan yang berbeda, apabila variabel intervening yang digunakan adalah variabel lain seperti kepuasan pelanggan atau kepercayaan.

4. Variabel pada penelitian ini disarankan untuk dapat dilakukan penelitian selanjutnya dengan objek penelitian pada perusahaan jasa lainnya seperti perbankan, leasing, forwarding, baik pada badan usaha 
milik negara atau swasta baik tingkat provinsi maupun nasional.

\section{DAFTAR PUSTAKA}

Arikunto, Suharsimi. 2002. Prosedur Penelitian, Jakarta: Rineka Cipta.

Bahareh Ghotbivayghan, Masoomeh Hoseinzadehshahri, and Mohammadreza Ebrahimi. 2015. Effect of Celebrity Endorsement on Consumer's Perception of Corporate Image, Corporate Credibility and Corporate Loyalty (Case Study: Novin Charm Company).Case Studies in Business and Management ISSN 2333-3324, Vol. 2, No. I

E. Murell Dawson and Elfreda A. Chatman. (200I). Reference group theory with implications for information studies: a theoretical essay.Information Research, Vol. 6 No. 3. Florida State University Tallahassee, Florida, USA.

Eun Jung Choi and Soo-Hyun Kim. 20I3. The Study of the Impact of Perceived Quality and Value of Social Enterprises on Customer Satisfaction and Re-Purchase Intention. International Journal of Smart Home Vol. 7, No. I.

FrouzanFar, Mohammad Hassan, Sorayya Meimar, and Faezeh Tagipour. 2012. The Role Of Reference Groups On Student's Cultural Values.Interdisciplinary Journal of Contemporary Research In Business.

Hair, Joseph F. Jr, Ralph E.Andersen, Ronal L. Tatham, William C Block. 2006. Multivariate Data Analysis, 8th Edition, New Jersey: Prentice Hall. Inc. Iryna Pentina, Victor R. Prybutok, and Xiaoni Zhang. 2008. The Role Of Virtual Communities As Shopping Reference Groups. Journal of Electronic Commerce Research, VOL 9, NO 2

Jalalkamali dan Nikbin, D. 2010. The Effects of Motivation on Purchase Decision.Interdisciplinary Journal of Contemporary Research Business, Vol. 2 No.8.

Jennifer Edson Escalas And James R. Bettman. 2005. Reference Groups, and Brand Meaning.Journal Of Consumer Research, Inc. Vol. 32
Kotler, Philip. 2002. Marketing Management I I th.New Jersey, Prentice Hall

Kotler, Philip and Kevin Lane Keller. 2009. Creating Customer Value, Satisfaction, and Loyalty. Customers are value maximizers. A Framework for Marketing Management. Fourth Edition. Published by Prentice Hall.

Long-Yi Lin and Ching-Yuh Lu. 20I0. The influence of corporate image, relationship marketing, and trust on purchase intention : the moderating effects of word-ofmouth. Tourism review : the official journal of the AIEST.- Bingley : Emerald, ISSN 1660-5373, ZDB-ID 24400I78. Vol. 65, 3, p. 16-34

Schiffman dan Kanuk, Amelia. 2004. Analisa Marketing Mix, Lingkungan Sosial, Psikologi Terhadap Keputusan Pembelian Online Pakaian Wanita.Juarnal Manajemen Pemasaran Petra.Vol. I, No. 2.

Schiffman, Leon G. dan Lesli Lazar Kanuk. 2000.Consumer Behavior, 7thEdition. Upper Saddle River. New Jersey: Prentice Hall Inc.

Seyed Alireza Mosavi and Mahnoosh Ghaedi. 20II. An examination of the effects of perceived value and attitude on customers' behavioral intentions in eshopping.African Journal of Business Management Vol. 6(5), Pp. 1950-1959

Smadi, Ziad Moh'd Ali, Bahjat Eid Al-jawazneh. 2011. The Consumer Decision Making Styles of Mobile Phones among the University Level Students in Jordan.International Bulletin of Business Administration ISSN: |45 I-243X Issue 10.

Sugiyono, 2010. Metode Penelitian Bisnis. Bandung : CV. Alfabeta. 